"Beau comme le tremblement des mains dans l'alcoolisme": A Cavalier History of Drugs and Intoxication in the Situationist International. In: Williams, Russell and Brennan, Eugene eds. Literature and Intoxication, Palgrave Macmillan, pp. 173-184 Reproduced with the permission of Palgrave Macmillan.

This extract is taken from the author's original manuscript and has not been edited. The definitive, published, version of record is available here: http://www.palgrave.com/page/detail/?K=9781137487650

\title{
"Beau comme le tremblement des mains dans l'alcoolisme": A Cavalier History of Drugs and Intoxication in the Situationist International
}

\section{Alastair Hemmens}

The relationship between the Situationists and intoxication is not a subject that has been explicitly explored before. However, those familiar with the literature by and about the SI will have noted the presence of drugs, both legal and illegal, in the groups' collective history as well as in the individual lives of its members. The practice of dérive, for example, which will be explored in more detail below, invariably involved intoxication of some sort, most often in the form of alcohol. Guy Debord, the group's co-founder and central theorist, was a famously unapologetic alcoholic; while Alexander Trocchi, the only Scottish member of the SI, was a heroin addict who explored his addiction to the narcotic through literature. These instances of drug use and intoxication are not merely anecdotal but should be considered from the perspective of both the historical epoch in which they took place and the critical theory of the Situationists. Indeed, one of the defining characteristics of the post-war period was the commensurate emergence of a mass consumer market for illicit drugs and the strong association of these drugs with counter-cultural movements. As a group that was both of their times and sought to go beyond these times, the SI had a characteristically complex and, above all, critical relationship to these new patterns of intoxication. Although Debord had his own (often overly romanticised) problems with alcohol and was not against the use of drugs in certain contexts, he was also deeply apprehensive about these social developments and, as will be seen, he believed that this new form of consumption was symptomatic of the destructive irrationality at the heart of the Society of the Spectacle and its subjects.

The Lettrist International (LI, the group that would form the first French section of the SI) originally evolved out of personal relationships and patterns of behaviour that were established within the alternative youth culture of Left Bank Paris in the early 1950s. During this period, the city witnessed the growth of a distinctly modern youth, as the number of school leavers going to university steadily increased and businesses started to cater to younger demographics. The Left Bank, specifically the neighbourhood on and around the Boulevard Saint Germain, became the focal point of this new scene. Not only was this area close to the main buildings of the Sorbonne university, it was also the haunt of existentialist philosophers and boasted many of the best jazz clubs in the city. Simply coming to drink here at all was, for many young people, a symbolic act of rebellion against their parents and the straight-laced social mores of an earlier European social order that the war and the Occupation had proven to be morally bankrupt. It was therefore no accident that the events of 
May ' 68 and the activities of revolutionary organisations such as the SI would later centre on this region of Paris.

Where, with whom, and how much you drank was a way of establishing not only personal but also political affiliations. Guy Debord and his comrades drank in the cheapest bars of the Left Bank, such as Chez Moineau, and had little or nothing to do with cafés like Les Deux-Magots and the Café de Flore that were home to the figures of Jean-Paul Sartre and Simone de Beauvoir. Indeed, these latter, were not even part of 'Saint German' as the 'Tribe', the name given by Debord and his drinking companions to themselves, experienced it (Mension 2001: 15). The 'Saint German' of the Tribe was primarily defined by heavy intoxication and delinquency. Debord, in particular, was able to consume huge quantities of alcohol, most often wine, spreading it throughout the day, but always managing to avoid passing out (Mension 2001: 50, 47). Ether cocktails were also an occasional feature (Mension 2001: 33). Fights were not an infrequent occurrence and the evenings could end with someone locked up overnight curtesy of the local police (Mension 2001: 38). While Debord received an allowance from his family that allowed him to fund this down-and-out lifestyle, many of his companions relied primarily on theft and panhandling in order to further intoxicate themselves (Mension 2001: 38). It would be easy to dismiss these alcohol-fuelled escapades as simply self-destructive and juvenile, and certainly there is an element of this, but it was also, or at least became, a self-conscious stance against modern life. Drunkenness meant a refusal to work, it signified dropping out of society and not adopting the roles it demanded. By taking 'Saint Germain' to its extreme, the Tribe avoided the mere posturing of the existentialist youth who would eventually settle down, get married, do their studies and get a job. 'Ne travaillez jamais', as Debord famously scrawled on a wall of the Rue de la Seine in 1952 (SI 1997: 338).

The consciously political character of this intoxication is particularly clear in the anticolonial gestures of the Tribe, which regularly frequented the Arab bistros of the Rue Galande. Jean-Michel Mension, a member of the group and a friend of Debord at this time, states: 'Hanging out with North Africans was a clear way of being against the bourgeoisie, against the morons, against the French' (Mension 2001: 25). The sentiment that Mension gives voice to here serves to underline the point that where you drank helped to demarcate your allegiances. To drink in an Arab bistro at this time was to be actively anti-French and anti-capitalist. Through these contacts the group also had access to marijuana, an intoxicant that was so exotic as to be hardly known at all in central Paris: 'we smoked hash on a regular basis. Nowadays everybody smokes hash [...] back then nobody did [...] we were just a tiny group of people who smoked. Hash then was a very new thing; you could smoke in the street - nobody had the faintest idea what it was' (Mension 2001: 24). These symbolic and countercultural stances against colonialism and 'the French' may have amounted to very little in and of themselves. However, the personal connections made through intoxication would later meaningfully inform the critical stances of the Situationist International in the context of the Algerian War of Independence and give its French section a genuinely international character with an ethnically diverse membership, in spite of its mostly Paris-centred geographical boundaries.

The mixture of ether, alcohol, mescaline and marijuana facilitated an on-going practice of critical dialogue within the group. It is clear from Mension's account that Debord was particularly attracted to other intelligent, rebellious drinkers with whom he shared his culture and with whom he developed his ideas (Mension 2001: 39-43). The talk and 
intoxication was often accompanied by walking to different bars, to a favourite location or simply by wandering about the city at random, however fancy took them. Over the course of several years this was to develop into an actual critical practice: the dérive, which, literally translated, means 'drift'. The Situationists defined the dérive as 'an experimental mode of behaviour linked to the conditions of urban society' (SI 1997: 13). It was experimental in that it was both a different way of experiencing urban space, outside the strict realm of circulation and consumption for which it had been intended, and it was an experiment that was supposed to create actual experimental results that could be analysed. Paris, which had hardly changed in the inter-war years, was over the course of the fifties and sixties going through a series of modernisation programmes that were not only destroying old areas but also creating the kind of bleak, inhuman modernist city spaces now most associated with concrete façades and vast housing projects. The dérive allowed the collection of the raw qualitative data these young revolutionaries required in order to make sense of these changes as well as to discover exactly what was wanting in a post-revolutionary Paris. In cultural-historical terms therefore it was a practice linked closely to the tradition of flanerie and to the discovery of the surreal in everyday urban space found in André Breton's Nadja (1928) or Louis Aragon's Le Paysan de Paris (1926). Where the dérive differed from its bourgeois and artistic forebears, however, was that it was at once a collective rather than an individual experience and that it always had an actively critical or political dimension.

Although not entirely necessary to the practice, intoxicants, in the form of alcohol or marijuana, could act in this context as an alternative agent of consciousness, a tool for the déreglement de sens, which would allow the drifter to create both a critical distance from the space and also to spark the imaginative leaps that would let it be altered. Raoul Vaneigem, who became a member of the SI in 1961, provides the example of a dérive in Sarcelles, a recently constructed housing development, in the early 1960s, where he and Debord got completely drunk beforehand on mescal (a type of strong Mexican alcohol) ostensibly, it seems, in order to induce a state of critical paranoia: 'Ce fut une véritable descente aux enfers que nos déambulations insensées, dans un ordonnancement de caserne qui rendait la rêverie et la flânerie impossibles. Les murs suintait cet ennui qui n'appelle d'autres divertissements que les jeux morbides de la violence et du crime' (Bott 2003: n.p.). While heavy drinking might sometimes aid in a rediscovery of the city as a site of adventure and collective meaning, in the context of these modernist constructions the gap between the intensity of the intoxication and the limitations of the space created a sickening sensation. Vaneigem does claim, moreover, that the subsequent headache was less a result of the copious amounts of alcohol they had just drank than the horror that he and Debord believed Sarcelles presaged for the future of humanity! The dérive therefore expanded the SI's use of intoxication in a manner that went beyond the kind of self-destruction that made one useless to the commodity system and, in its place, or at least alongside, made it into a constructive tool in the development of a critical discourse on capitalism and its urban spaces.

The dérive and the activities of the Tribe offer us a collective picture of the use of intoxicants by the Situationists and the protean-groupings that went on to form it. The individual relationship of members of the SI to intoxication could, however, prove to be much more extreme and problematical. The most obvious example, being the most familiar, is that of Guy Debord. Debord explores his relationship with alcohol in a short chapter of his Panégyrique, first published in 1989, towards the end of his life. He tells us, for example, that drinking has been his most enduring passion, something that he knew how to do well, and he 
claims to have single-handedly proven the French worthy of the phrase, 'Il y en a qui ne se sont soulés qu'une seule fois, mais elle leur a duré toute la vie' (Debord 2006: 1668-1669). In extreme drunkenness, Debord (2006: 1669) tell us, he discovered the experience of 'une paix magnifique et terrible, le vrai goût du passage du temps'. This desire to revel in the feeling of time, of simply existing, is loosely tied to Debord's concern with active participation in history and of creating experiences that reach outside of the constraints of modern social life. Alcohol renders one incapable of work and, at the same time, provides an immediate subjective experience of the presence of time passing. The implication therefore is that drinking, done well, gives access to a perspective that is at once enjoyable, critical and playful, just as Debord made use of it in the dérive. Without alcohol, one suspects, Debord would not have had access to certain experiences and personal contacts that laid the groundwork for his theories.

Critics have tended subtly to romanticise the alcoholism of Debord, as well as his later years more generally. For much of his life, Debord had maintained a largely playful and creative relationship with alcohol. Later on, however, Debord developed an increasingly debilitating and painful addiction to the substance. In the years before his suicide in 1994, heavy drinking had left him suffering from crippling gout, insomnia and even vertigo. Andrew Hussey (2001: 363) also suggests that Debord may have suffered from peripheral neuritis, 'a disease of the nerve endings, common in alcoholics, which burns away all feeling in the extremities'. Indeed, in Panégyrique, Debord, is much more knowing and ambiguous about his alcoholism than simply vaunting it as a virtue. This stance is made clear by the quote from de Tocqueville that prefaces this chapter of the book: 'la plupart de ceux qui ont laissé des Mémoires ne nous ont bien montré leurs mauvaises actions ou leurs penchants que quand, par hasard, ils les ont pris pour des prouesses ou de bons instincts' (Debord 2006: 1668). Underlying the celebration of alcohol there is therefore a certain degree of detached self-criticism. Debord notes with irony, for example, that, in all the calumnies and false criticisms launched against him over the years, not once has anyone used his drunkenness, which he describes as 'ce côté peut-être contestable de ma personnalité' (2006: 1669), as an argument against his ideas. Moreover, Debord admits that being in a state of perpetual intoxication has left him little time to write, though justifies this admission, 'l'écriture doit rester rare, puisque avant de trouver l'excellent il faut avoir bu longtemps' (2006: 1670). He also writes poignantly of the illnesses drink had brought upon him, 'il y a des matins émouvants mais difficiles', and quotes Lautréamont, 'Beau comme le tremblement des mains dans l'alcoolisme' (Debord 2006: 1670). Thus, while insisting on a certain beauty and prowess in his love of drink, Debord is aware that his position is deeply suspect and subtly hints at this to his readers. Indeed, there is tragedy in these lines that emphasises the fact that the problems associated with long term alcoholism were most likely a contributing factor in the decision of Debord to take his own life in 1994.

The figure of Alexander Trocchi provides another prominent example of a Situationist with a problematic relationship to intoxication. Born in Glasgow in 1925, Trocchi began his engagement with the avant-garde as a poet, editing the influential review Merlin and writing pornographic fiction for the Olympia Press. According to Andrew Hussey (2001: 124), Trocchi had picked up the use of heroin in Glasgow and became fully addicted to the drug by the time he was living in Paris in the late 1950s. Trocchi had made quick friends with Debord and the members of the LI with whom he shared a similar desire to merge revolution and avant-garde creative action. Although it is unclear at what exact moment Trocchi joined the 
Situationist International, it seems that, despite not being present at the founding conference in 1957, he was made a fully-fledged member early on. After being made a Situationist, however, Trocchi was to spend much of his time in absentia as he relocated to the United States. Having replaced Paris for New York, Trocchi relied in part on his wife Lyn prostituting herself on the Lower East Side to fund his addiction. In the US he courted a great deal of controversy. For example, while on bail for a drug offence, he was asked to take part in a discussion about drugs on a national television talk show, where he proceeded to shoot up live on stage. Trocchi also fell afoul of the law when he was charged with supplying heroin to a minor, an offence for which he could have been given the death penalty. Fortunately, with the help of some friends, he was able to able to escape back to Europe. Resigning from the SI in 1964, Trocchi was to spend the rest of his life in the UK, using a drug supply provided by the NHS, and died of pneumonia in 1984.

It may be objected that Trocchi, who was absent from Europe and had no great deal of contact with the group for many years, was not truly a member of the SI in this period. It is worth noting, however, that his imprisonment by the New York police in 1960 for supplying drugs to a minor led to the only direct statement by the SI as a whole about drugs. At the $4^{\text {th }}$ conference of the SI, held in London in September 1960, the organisation agreed on a statement in which they declared that the charges were false (they were probably true) and a simple police provocation (SI 1997: 160). More importantly, they affirmed that 'drug taking is without importance' (SI 1997: 160). As part of this statement, the SI called upon 'all British intellectuals who value liberty to demand the setting free of Alexander Trocchi, who is beyond doubt England's most intelligent creative artist today' (SI 1997: 160). The conference resolution was later to be followed by a text, 'Hands of Alexander Trocchi', in which the SI repeated their call for the release of Trocchi and argued, moreover, that his use of drugs should be seen in the long line of artists and medical professionals who had experimented with them (Jorn 1960). They noted in particular that the poet Henri Michaux had openly and very publicly written several recent publications under the influence of mescaline (Jorn 1960). Trocchi, it was argued, was a 'new type of artist', 'a pioneer of a new culture and a new comportment' who, like Michaux, deserved 'certain rights' that belonged to such artists (Jorn 1960). By situating the drug use of Trocchi within the artistic and experimental context, the Situationists hoped to appeal to the artistic establishment, recasting his addiction as pioneering research, and thereby to save him from a brutal state execution.

Trocchi recorded his thoughts on and experiences of heroin addiction in the US in his novel Cain's Book. First published in the UK in 1960, the text immediately became the subject of an obscenity trial for its liberal use of the word 'cunt' and its explicit depiction of sex and illicit drug use. The book itself describes how Trocchi sees heroin use, along with other drugs but particularly heroin, as a 'critical technique' that allows a person an otherwise unattainable viewpoint on society: "to attain [...] the serenity of a vantage point "beyond" death' (1992: 41). It is clearer what Trocchi means by this when he states: 'it is that the organism has a sense of being intact and unbrittle, and, above all, inviolable. For the attitude born of this sense of inviolability some Americans have used the word "cool"" (1992: 11). This notion of being 'inviolable', and indeed the term itself, is repeatedly used in associated with heroin use throughout the book. Heroin, for Trocchi, puts one in a subjective space, 'a painless theoretical region', that is 'beyond anguish' and 'unmoral' (1992: 11). Essentially, Trocchi is stating that heroin use allows him to place himself existentially, subjectively, as a pure nihilist and thus in a negative, and apparently objective, opposition to the world that 
allows him to see it as it truly is. It is a 'chemistry of alienation' (Trocchi 1992: 33), creating a critical distance between the drug user and normal social life: 'There is no more systematic nihilism than the junkie in America' (1992: 36). One might object, however, that this 'coolness' is in fact the very narcissistic detachment that has increasingly characterised the capitalist subject since the mid-twentieth century. Indeed, certain statements by Trocchi about heroin use seem perfectly to contradict his claims for the 'critical technique' of the drug: 'Under heroin one adapts oneself naturally to a new habitat. It is possible to live in a doorway, on someone's couch, or bed, or floor, always moving, and turning up from time to time at known places' (1992: 36). Here the heroin user, far from developing the intellectual capacity, seems rather to be reduced to the kind of pseudo-animal state of mere survival and adaptability that Vaneigem would go on to condemn as characteristic of the capitalist subject in 1967. Indeed, the very notion of searching for 'inviolability' through a narcotic already assumes a certain desire to immure oneself from the reality of alienation or for an illusory escape. What Trocchi proclaims to be a 'critical technique' could equally be interpreted as a survival mechanism for dealing with the barbarism of modern life. Certainly, in the more lucid moments of his work, Trocchi hints at just such a self-criticism, 'I have needed drugs to abolish within myself the painful reflection of the schizophrenia of my times' (cited in Scott 1991: 104). Reading Trocchi here, one is left wondering how heroin, which apparently abolishes reflection, could aid in the development of any critical position at all. Indeed, these points are never developed and the link between drugs and insanity seems no more than a throwaway line; Trocchi instead turns what should be a moment of self-understanding into one of pseudo-radicalism. This connection between insanity and drug use is, however, an aspect that Debord would develop in his critique of drug consumption in the post-war period.

Debord puts forward this critique of drug culture and drug users in just a few passages in his 1988 text Commentaires sur la Société du Spectacle. The context for his critique is found in a section on the role of the mafia in the history of the twentieth century and its complicity with the state in the development of modern social conditions. He notes that alcohol prohibition provided the financial basis for the development of the mafia as a political force and that, since the legalisation of alcohol, the same is now true of the drug trade. The mafia acts as a capitalist enterprise, albeit one outside the law, which is simply a mirror image of the state and official structures of consumption. In this situation 'les stupéfiants', Debord states, have simply become the 'marchandise-vedette des consommations illégales' (Debord 2006: 1632). In other words, by the late 1980s it is evidently clear that, far from embodying a radical perspective or alternative lifestyle as Trocchi had suggested in the 1960s, drug consumption simply constitutes a form of consumerism, only less banal than any other due to the frisson of its being outside official state sanction. It is not therefore a practice that can be opposed to Spectacular ways of modern life, but rather the flipside of the same process of commodification.

Debord ties the rise of drug use in capitalist society directly to the corrosive effects of capitalism on the psyche of its subjects. The Spectacle, which is the domination of all human life by the economy, separates human beings from the possibility of authentic experience by strictly limiting all society to relations between commodities. As such, Debord (2006: 1611) argues, the individual is not allowed to develop their own personality but must conform to this situation or receive no recognition from that society. That is to say, rather than create their own identity, the subject must identify with an ever-changing set of commodities. 'La drogue', Debord states, 'aide à se conformer à cette organisation des choses; la folie aide à la 
fuir' (2006: 1611). It is useful to compare this quote with that of Trocchi who claims heroin helps him deal with the schizophrenia of modernity. Where Trocchi argues drugs aid the individual to avoid the traps of modern life, Debord believes it does the complete opposite, it helps one to conform or to adapt to capitalism. Faced with either insanity, drug use or being a complete pariah, the subject of the Spectacle is placed in an almost impossible situation. The only way out, for Debord, is to study the logic of this society and to seek to overcome its organisation. However, as he states elsewhere in the Commentaires, the subject, in particular the drug user, is now ill-equipped to do any such thing and tends to become just as illogical as the system in which he or she was formed: 'la tendance se répand aussi parmi les spectateurs de vouloir être aussi illogiques que le spectacle [...] Enfin, la logique n'est pas facile, et personne n'a souhaité la leur enseigner. Aucun drogué n'étudie la logique; parce qu'il n'en a plus besoin, et parce qu'il n'en a plus la possibilité' (2006: 1610). Deadening to the schizophrenia of the times, Debord suggests, the self-medication of the drug user eventually results in a permanently passive relationship in which the transformation of society can neither be thought through nor felt necessary. From this point of view, Trocchi's heroin experience, far from being radical or critical, becomes both an example and metaphor of the abject alienation of capitalist subjects.

What then were drugs and intoxication to the SI? In the early days, a shared love of alcohol and a desire to reject the post-war world brought together a number of intelligent and rebellious youth on the Left Bank of Paris. Intoxication helped the conversation to flow and, particularly in the case of the dérive, could contribute in some small way to the creative discoveries and analyses that the Lettrists and later the Situationist International itself would develop into a critical theory. In the lives of individual members, such as Trocchi and Debord, intoxication also had a much darker and even deadly aspect to it. The Situationists therefore were not averse to various forms of intoxication, but, by and large, they set themselves apart from the emerging hippy drug culture of the 1960s and 1970s. Even in the earliest, pre-Situationist writings, Gilles Ivan imagines a social space where 'Il y aura des pièces qui feront rêver mieux que des drogues' (SI 1997: 19). Henri Lefebvre, a one-time friend of Debord, notes that, in contrast to the Provos in Amsterdam, in his experience the member of the Situationist International only drank alcohol (with maybe a little mescaline), 'That wasn't how they wanted to create new situations' (Ross 1997: 75). While the picture was perhaps a bit more complex than Lefebvre states here, it is certainly true that the Situationists, Trocchi perhaps excluded, did not believe drugs could play any transformative or revolutionary role in social movements against capitalism. On the contrary, for the Situationists drugs were at best 'without importance', as the declaration of the $4^{\text {th }}$ conference of the SI had clearly stated, and at worst, as Debord would argue in his later work, they were a counter-revolutionary measure that made it easier to adapt to the barbaric conditions of Spectacular society.

\section{Bibliography}

Bott, François, 'Raoul Vaneigem, Refus et passions' in Le Monde, 12 September 2003.

Debord, Guy, Euvres (Paris: Gallimard, 2006)

Hussey, Andrew, The Game of War, The Life and Death of Guy Debord (London: Johnathan Cape, 2001) 
Jorn, Asger, Guy Debord, Jacqueline de Jong, 'Hands off Alexander Trocchi', 1960. $<$ Notbored.org, web accessed, 25 September 2014>

Mension, Jean-Michel, The Tribe (San Francisco: City Lights Books, 2001)

Ross, Kristin, 'Lefebvre on the Situationists, An Interview', October, vol. 79, winter 1997.

Scott, Andrew Murray, Alexander Trocchi: The Making of a Monster (Edinburgh: Polygon, 1991)

Situationist International (SI), Internationale situationniste, édition augmentée (Paris: Arthème Fayard, 1997)

Trocchi, Alexander, Cain's Book (London: John Calder, 1998). 